\title{
Board of Director Diversity and Corporate Performance: The Case of South Korea*
}

\author{
HANNAH JUN* AND HYOJIN KIM***
}

\begin{abstract}
Recent corporate governance scandals (such as those at Uber) have reemphasized the importance of proper oversight and monitoring to ensure sustainable corporate performance. While the issue of how to improve corporate governance is not a new one, we have seen a resurgence of interest in whether diversity - particularly at the board of director level - improves this oversight function and, ultimately, corporate performance. This paper contributes to the academic discussion on board of director diversity with a focus on gender diversity and introduces Korea as a subject of analysis given that corporate governance remains a key area of concern for the local market and that, despite having had a female president in its relatively short democratic history and launching the WomenCorporateDirectors Korea branch in 2016, it ranks last among OECD (Organisation for Economic Co-operation and Development) member states in terms of female representation on corporate boards. We contribute to the academic debate on the relationship between gender diversity on corporate boards and corporate performance by undertaking a comprehensive literature review on board diversity and corporate performance, introducing data on Korean boards of directors and generating testable hypotheses for future research.
\end{abstract}

Keywords: Board of Directors, Corporate Governance, Corporate Performance, Diversity, Gender, Korea, Women

* This work was supported by the Ministry of Education of the Republic of Korea and the National Research Foundation of Korea (NRF-2016S1A5A8019864).

** Assistant professor, Ewha Womans University, Seoul, South Korea;

E-mail: hannahjun@ewha.ac.kr

*** Graduate student, Ewha Womans University, Seoul, South Korea;

E-mail: hyonala@gmail.com

DOI: 10.16934/isr.18.2.201712.39 


\section{INTRODUCTION}

Decades of research have been devoted to examining the function and importance of corporate boards of directors in ensuring proper oversight and monitoring (e.g., Bebchuk and Weisbach 2010). In economic and financial research, there is a broad consensus that the board of directors is a crucial element of a firm's corporate governance structure (Baysinger and Butler 1985; Daily et al. 2003, Fama and Jensen 1983; John and Senbet 1998; Williamson 1983). With the growth of firms and control being relegated to management (rather than being tied closely with ownership, as is the case in the earliest stage of business), we have seen strong theoretical justification for the monitoring role carried out by the board of directors (Earle 1979; Fama and Jensen 1983; Goodstein and Boeker 1991).

But recent scandals such as that of Uber (see Table 1) have shown that the issue of whether boards of directors are, in fact, properly equipped to fulfill this monitoring function is not going away. Specifically, despite evidence of an unethical and misogynistic corporate culture - in many ways exemplified by the practices of its chief executive - this was left largely unchecked by the company's board of directors, at least until its exposure led to the resignation of its CEO.

\section{TABLE 1. TIMELINE OF KeY EVENTS AT UbER}

\begin{tabular}{cl}
\hline \multicolumn{1}{c}{ Date } & \multicolumn{1}{c}{ Event } \\
\hline December 8, 2014 & $\begin{array}{l}\text { The Delhi region banned Uber after one of its drivers appeared in court on } \\
\text { suspicion of raping a passenger who dozed off during a ride home. }\end{array}$ \\
\hline December 9, 2014 & $\begin{array}{l}\text { In Madrid, a commercial court judge sided with a taxi association complaint, } \\
\text { saying that Uber must cease driving in Spain until a lawsuit contesting its right to } \\
\text { operate can be heard. In Bangkok, the Thai transport authorities ordered Uber to } \\
\text { shut down after finding that its drivers lacked the registration and insurance } \\
\text { needed to operate commercial vehicles. }\end{array}$ \\
\hline February 4,2015 & $\begin{array}{l}\text { The South Korean government rejected a regulatory compromise suggested by } \\
\text { Uber and vowed a "strong crackdown" on its ride-hailing services. }\end{array}$ \\
\hline April 6, 2016 & $\begin{array}{l}\text { A passenger who got behind the steering wheel of an Uber car so that the driver } \\
\text { could nap led the police on a highway chase in central New York. }\end{array}$ \\
\hline June 9, 2016 & $\begin{array}{l}\text { Uber and two of its senior European executives were convicted and fined nearly } \\
\text { \$500,000 in France on Thursday for running an illegal transportation business. }\end{array}$ \\
\hline February 19,2017 & $\begin{array}{l}\text { Ex-Employee was sexually harassed by her direct supervisor during her time at } \\
\text { Uber and that after she reported those claims to the human resources department, } \\
\text { they were ignored. }\end{array}$ \\
\hline May 11,2017 & $\begin{array}{l}\text { Uber should be regulated as a transportation company and not a tech service, an } \\
\text { adviser to Europe's top court said. }\end{array}$ \\
\hline June 7,2017 & $\begin{array}{l}\text { Uber fired a senior executive who obtained medical records of a woman who was } \\
\text { raped by an Uber driver in India. }\end{array}$ \\
\hline June 13,2017 & $\begin{array}{l}\text { Uber board member David Bonderman, who spurred outrage after making a sexist } \\
\text { remark at a staff meeting, resigns. }\end{array}$ \\
\hline June 15,2017 & \begin{tabular}{l} 
A woman who was raped by her Uber driver in India filed a lawsuit against Uber. \\
\hline
\end{tabular}
\end{tabular}


Date

June 21, 2017 Travis Kalanick stepped down as chief executive of Uber after a shareholder revolt made it untenable for him to stay on at the company.

July 18, 2017 A lawsuit against Uber says it has violated New York City's human rights laws by providing too few vehicles that can accommodate wheelchairs.

August 11, 2017 A prominent investor in Uber sued Mr. Kalanick, who was ousted as Uber's leader in June, in an attempt to remove him from the company's board of directors.

August 27, 2017 Uber chose Dara Khosrowshahi (Expedia) to be its chief executive.

Source: The New York Times (2014a) for December 8, 2014; The New York Times (2014b) for December 9, 2014; The New York Times (2015a) for February 4, 2015; The New York Times (2016a) for April 6, 2016; The New York Times (2016b) for June 9, 2016; The New York Times (2017a) for February 19, 2017; The New York Times (2017b) for May 11, 2017; The New York Times (2017c) for June 7, 2017; CNBC (2017) for June 13, 2017; The New York Times (2017d) for June 15, 2017; The New York Times (2017e) for June 21, 2017; The New York Times (2017f) for July 18, 2017; The New York Times (2017g) for August 11, 2017; The New York Times (2017h) for August 27, 2017.

In some ways, the recent case of Uber has become a textbook case for the argument that greater diversity in corporate boards may improve corporate performance - both in terms of financial and social performance. The rationale is that in order for boards to monitor management properly and take into account interests of minority shareholders (and stakeholders) that would otherwise go unnoticed, boards should be independent and diverse enough to be able to challenge management when necessary. In other words, directors who look and act in a similar way to management may be inclined to follow management, even if this may protect the interests of managers (asset deployers) at the expense shareholders (asset providers). In the case of Uber, the board of directors (see Table 2) includes just two female directors out of 11 - with one appointed after former CEO Travis Kalanick was ousted from his role.

\section{TABLE 2. BOARD OF DIRECTOR COMPOSITION AT UBER (AS OF NOVEMBER 2017)}

\begin{tabular}{|c|c|c|c|}
\hline Name & Primary Company & Gender & Age \\
\hline Garrett Camp & Uber Technologies, Inc. & Male & -- \\
\hline Travis Kalanick $^{(\mathrm{a})}$ & Sociable Labs, Inc. & Male & -- \\
\hline Ryan Graves & Homebrew Management LLC & Male & 34 \\
\hline Arianna Huffington & Thrive Global Holdings, Inc. & Female & 66 \\
\hline Wan Martello & Nestlé S.A. & Male & 59 \\
\hline David Trujillo & TPG Capital, L.P. & Male & 41 \\
\hline Cheng Wei & Didi Chuxing Technology Co., Ltd. & Male & -- \\
\hline Matthew Cohler & Asana, Inc. & Male & 40 \\
\hline Yasir bin Othman Al-Rumayyan & Public Investment Fund & Male & 47 \\
\hline Ursula Burns $^{(b)}$ & VEON Ltd. & Female & 58 \\
\hline John Thain ${ }^{(b)}$ & GSVentures & Male & 61 \\
\hline
\end{tabular}

Notes: (a) Mr. Kalanick left the CEO role in June 2017, but retains his seat on the board of directors; (b) Ursula Burns and John Thain were appointed by Mr. Kalanick on September 29, 2017 "to dramatically restructure the Board and significantly alter the company's voting rights"

Source: Bloomberg (2017) 
While diversity on boards of directors may include ethnic diversity, professional (or occupational) diversity and age diversity, there has been a lot of focus on the issue of gender diversity. In fact, international organizations such as WomenCorporateDirectors (WCD) have been launched specifically to raise awareness of the potential benefits of gender diversity on corporate boards of directors - particularly with regards to providing diversity of opinion and perspective. In this paper, we contribute to the academic discussion on board of director diversity with a focus on gender diversity. In addition, we introduce Korea as a subject of analysis given that corporate governance remains a key area of concern for the local market and that, despite having had a female president in its relatively short democratic history and launching the WomenCorporateDirectors Korea branch in 2016, it ranks last among OECD (Organisation for Economic Co-operation and Development) member states in terms of female representation on corporate boards.

This paper examines the theoretical justification for boards of directors, the argument for board of director diversity and the state of board of director diversity in Korea. In doing so, this paper contributes to the academic debate on the relationship between gender diversity on corporate boards and corporate performance and generates testable hypotheses to guide future research in this field.

\section{THEORETICAL JUSTIFICATION FOR BOARDS OF DIRECTORS}

Within a corporation, managers (or asset deployers) are responsible for day-to-day operations of the business. We can expect this to result in information asymmetry, whereby managers may know more than shareholders (or asset providers) in almost every sphere of decision-making. The danger is that this information asymmetry may create conflicts of interest, whereby asset deployers act in ways that benefit the former at the expense of asset providers. Thus at its core, the board of directors aims to protect and promote the interests of asset providers (shareholders) by monitoring asset deployers (management), measuring performance of top executives and rewarding (or penalizing) performance and results (Byrd and Hickman 1992; Miller 2002). 


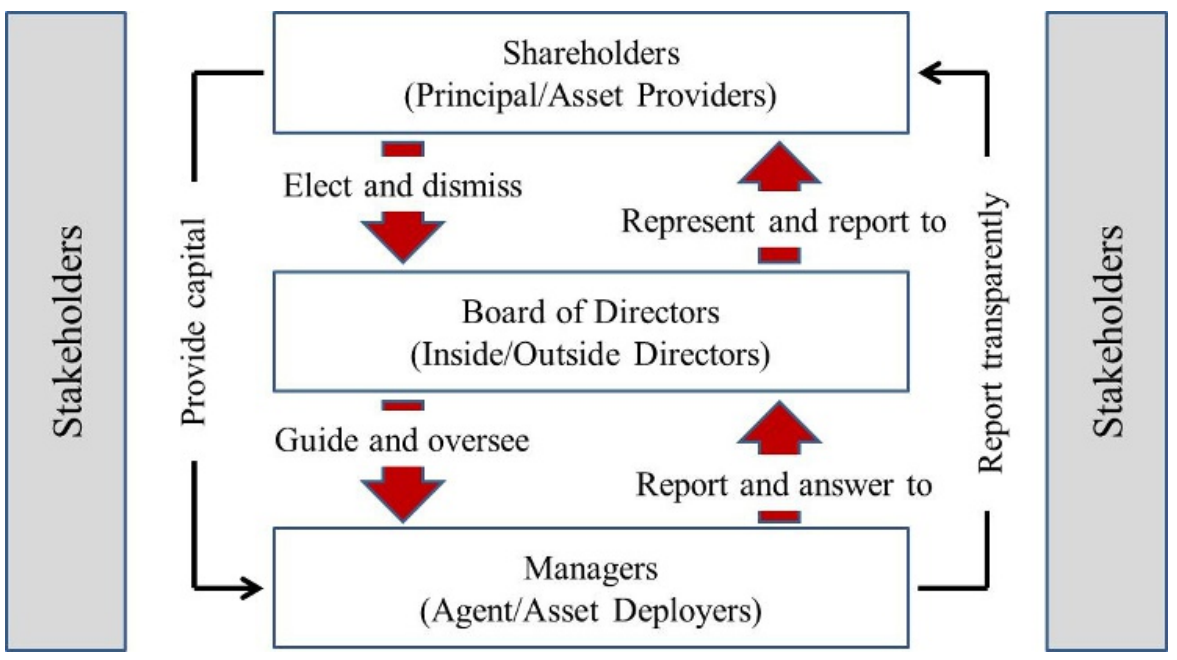

FIGURE 1. BASIC CORPORATE GOVERNANCE STRUCTURE

Many theoretical perspectives have been used to justify the role of boards of directors, including resource dependence theory (Johnson et al. 1996; Pfeffer 1972; Pfeffer and Salancik 1978) and stewardship theory (Muth and Donaldson 1998). In addition, much literature has looked at monitoring (Hillman and Dalziel 2003; Peasnell et al. 2005) and decision control systems (Fama and Jensen 1983) of corporate boards on the basis of agency theory, which is concerned with aligning interests of asset providers and asset deployers. Within this field, we have seen growing interest in the monitoring function of boards following corporate scandals such as Enron and WorldCom (e.g., Campbell and Mínguez-Vera 2008) particularly with regards to board composition, as monitoring requires an appropriate mix of experience and abilities to assess management effectively (Hillman and Dalziel 2003).

\section{ARGUMENT FOR BOARD OF DIRECTOR DIVERSITY}

In addition to literature on board composition (Hillman et al. 2001; Lawrence and Stapledon 1999; Lynall et al. 2003) and size (Jensen 1993; Raheja 2005; Yermack 1996), we have seen studies that examine the correlation between board of director diversity and corporate performance. While diversity can be distinguished between observable (e.g., gender, age, ethnicity) and non-observable (e.g., education, values, personality) diversity (Boeker 1997; Erhardt et al. 2003; Kilduff et al. 2000; Maznevski 1994; Pelled 1996; Watson et al. 1998), most studies on diversity and performance have centered on observable diversity with a special focus on gender (e.g., Campbell and Mínguez-Vera, 2008). Research on board of 
director gender diversity and performance (e.g., Farrell and Hersch 2005) can be narrowed down even further into studies examining financial performance and those analyzing non-financial performance.

With regards to board of director diversity and its impact on financial performance, we have seen a large number of studies that look at the relationship between the ratio of female directors on boards and financial performance (e.g., Adams and Ferreira 2009; Carter et al. 2003; Erhardt et al. 2003; Shrader et al. 1997). At the same time, we find that evidence and findings on this relationship are mixed (Haslam et al. 2010; Post and Byron 2015). For example, past studies have found a positive relationship between female representation on boards and corporate performance, evidence of a negative link and some finding no significant link at all (see Joecks et al. 2013).

For studies that have shown a positive relationship, scholars such as Carter et al. (2003) investigated the relationship between gender (or minorities) diversity in a sample of Fortune 1000 firms and found that a higher percentage of women on the board increased firm value, thus suggesting that a more diverse boardroom may be better equipped to monitor management. Campbell and Minguez-Vera (2008) also found a positive relationship between corporate value and the percentage of women on the board in a sample of firms from Spain, although the presence of women on the board did not seem to affect firm value. This study suggests that greater diversity can promote a better understanding of the marketplace by matching corporate boardroom diversity with diversity of potential customers. As such, the firm may be able to enhance its ability to enter markets and increase creativity and innovation.

Bonn (2004) discovered a positive relationship between the percentage of women on the board and a firm's market-to-book ratio, based on a sample drawn from the top 84 Australian manufacturing companies in 1999. But in a follow-up comparative study between Japan and Australia, Bonn et al (2004) obtained different results when analyzing the relationship between gender (and age) of board directors and corporate financial performance as measured by return on assets (ROA) and market-to-book value ratio for a sample of 169 Japanese and 104 Australian manufacturing firms. Specifically, while there seemed to be a positive relationship between the ratio of women directors and corporate performance for Australian firms, there were no significant effects of gender diversity in the Japan case.

But while there has been much research that showed a positive relationship between female boardroom participation and performance, some studies found neutral or negative relationships. For example, Dobbin and Jung (2013) found in a study of 432 U.S. companies that participation by women directors had a negative effect on stock value and no effect on profits when measuring share value and profits. Haslam et al. (2010) also analyzed the 
relationship between percentage of female directors and corporate financial performance, as measured by ROA, ROE (return on equity) and Tobin's Q for a sample of UK FTSE 1000 companies between 2001 and 2005. The study found a negative relationship with market measures through a Tobin's Q analysis and no correlation with ROA and ROE. These findings were echoed in a 2010 study by Bøhren and Strøm, which analyzed panel data of about 1,200 Norwegian firms between 1989 and 2002. with performance measure by Tobin's Q, ROA and ROS (Return on Sales). Their findings suggested a negative relationship between gender diversity and Tobin's Q, ROA and ROS (return on sales) for the Norwegian sample.

In Korea's case, a direct empirical study of board of director diversity and corporate performance is challenging primarily because there have been so few women directors on corporate boards. At the same time, we may be able to make broader linkages between the lack of diversity and corporate governance concerns in Korea. For example, one concern about the Korean market is the so-called "Korea discount," where the KOSPI is structurally undervalued vis-à-vis other Asian stock markets (The Economist 2012). While part of this has to do with potential geopolitical risk, another element is poor corporate governance at family-owned, family-managed conglomerates, or chaebols. While Korea introduced legislation to accommodate outside directors (or directors who are not employees or stakeholders in the company) on corporate boards following the Asian financial crisis of the late 1990s, this was with the goal of improving transparency and instituting a proper a monitoring mechanism. But as in other markets, it is questionable whether outside directors are truly independent - especially in a country as ethnically homogenous as Korea. It is within this context that we explore the potential role gender diversification can play in improving the function of corporate boards of directors in the Korean case.

\section{KOREA AND BOARD OF DIRECTOR DIVERSITY}

There have been more intense calls for greater female representation on boards of directors on a global scale. In some countries, we find the existence of quotas that are meant to enforce gender diversity (see Table 3). For example, Iceland, Norway and Spain all have quotas of $40 \%$ for corporate boards, while Belgium, France, Germany and Italy have quotas of at least $20 \%$, respectively. India and Israel have set quotas at above 0 (in other words, at least one board director should be female). 
TABLE 3. NATIONAL QUOTAS FOR WOMEN ON CORPORATE BOARDS

\begin{tabular}{ccc}
\hline Country & Income Group & Quota (\%) \\
\hline Belgium & High income: OECD & $33 \%$ \\
\hline France & High income: OECD & $20 \%$ \\
\hline Germany & High income: OECD & $30 \%$ \\
\hline Iceland & High income: OECD & $40 \%$ \\
\hline India & Lower middle income & $>0$ \\
\hline Israel & High income: OECD & $>0$ \\
\hline Italy & High income: OECD & $33 \%$ \\
\hline Norway & High income: OECD & $40 \%$ \\
\hline Spain & High income: OECD & $40 \%$ \\
\hline
\end{tabular}

Source: World Bank (2016)

Keeping this in mind, it is not surprising that we find very high levels of gender diversity on corporate boards for those countries that have designated quotas (see Table 3). At the same time, we notice there are several countries that have high female representation on boards of directors even without legislation on quotas. For example, female representation on corporate boards in Australia, Austria, Denmark, Finland, Latvia, the Netherlands, New Zealand, Portugal, Slovenia and the United Kingdom was at least $20 \%$. In this sense, the presence of quota legislation may not be a necessary condition for greater gender diversity on boards of directors.

\section{TABLE 4. FeMALE SHARE OF SEATS ON BOARDS OF THE LARGEST PUBLICly LiSTED} COMPANIES (\%)

\begin{tabular}{lccc}
\hline Country & 2010 & 2013 & 2016 \\
\hline Australia & 10.2 & 15.3 & 23.1 \\
\hline Austria & 9.0 & 13.0 & 20.0 \\
\hline Belgium & 10.0 & 17.0 & 27.0 \\
\hline Canada & 12.9 & 12.7 & 19.4 \\
\hline Chile & 2.2 & 2.8 & 4.7 \\
\hline Czech Republic & 12.0 & 11.0 & 9.0 \\
\hline Denmark & 18.0 & 23.0 & 27.0 \\
\hline Estonia & 7.0 & 7.0 & 8.0 \\
\hline Finland & 26.0 & 30.0 & 30.0 \\
\hline France & 12.0 & 30.0 & 37.0 \\
\hline Germany & 13.0 & 21.0 & 27.0 \\
\hline Greece & 6.0 & 8.0 & 9.0 \\
\hline Hungary & 14.0 & 11.0 & 11.0 \\
\hline Iceland & 16.0 & 48.0 & 44.0 \\
\hline
\end{tabular}




\begin{tabular}{|c|c|c|c|}
\hline Country & 2010 & 2013 & 2016 \\
\hline Ireland & 8.0 & 11.0 & 16.0 \\
\hline Israel & 14.0 & 15.7 & 18.1 \\
\hline Italy & 5.0 & 15.0 & 30.0 \\
\hline Japan & 0.9 & 1.7 & 3.4 \\
\hline Korea & 1.7 & 1.9 & 2.1 \\
\hline Latvia & 23.0 & 29.0 & 28.0 \\
\hline Luxembourg & 4.0 & 11.0 & 13.0 \\
\hline Mexico & 6.9 & 5.8 & 5.2 \\
\hline Netherlands & 15.0 & 25.0 & 28.0 \\
\hline New Zealand & 12.2 & 18.9 & 22.5 \\
\hline Norway & 39.0 & 42.0 & 41.0 \\
\hline Poland & 12.0 & 12.0 & 20.0 \\
\hline Portugal & 5.0 & 9.0 & 14.0 \\
\hline Slovak Republic & 22.0 & 24.0 & 14.0 \\
\hline Slovenia & 10.0 & 22.0 & 24.0 \\
\hline Spain & 10.0 & 15.0 & 20.0 \\
\hline Sweden & 26.0 & 26.0 & 36.0 \\
\hline Switzerland & 9.2 & 10.9 & 13.2 \\
\hline Turkey & 10.0 & 8.0 & 12.0 \\
\hline United Kingdom & 13.0 & 21.0 & 27.0 \\
\hline United States & 12.3 & 12.2 & 16.4 \\
\hline OECD - Average & 12.2 & 16.8 & 20.0 \\
\hline Brazil & 4.7 & 5.1 & 6.0 \\
\hline China (People's Republic of) & 8.0 & 8.4 & 9.4 \\
\hline Colombia & 9.6 & 6.0 & 11.4 \\
\hline India & 4.5 & 6.5 & 11.4 \\
\hline Indonesia & 4.8 & 6.0 & 5.7 \\
\hline South Africa & 16.4 & 17.9 & 19.0 \\
\hline
\end{tabular}

Source: OECD Statistics (http://stats.oecd.org/index.aspx?queryid=54753\#)

At the same time, we notice in Table 3 that Korea and Japan share the distinction of having the two lowest percentages of female representation on corporate boards within the OECD - this being the case for 2010, 2013 and 2016. This begs the question as to why this is the case. While a more comprehensive comparative study between the two countries may be beneficial in developing the academic literature further, we propose examining the Korean market in detail first.

Regarding general legislation on corporate boards of directors, we note that there were at least two distinct periods in which we saw heightened interest in board of director composition. The first was during the aftermath of the Asian 
Financial Crisis in the late 1990s. Given concerns that corporate boards lacked transparency and were not acting in the best interest of investors, regulations immediately after the crisis included the requirement that outside (or independent) directors constitute at least one-quarter of total board members for listed firms - this percentage was increased to $50 \%$ in 2001 for firms with a book value of assets exceeding KRW2 trillion, or roughly US\$ 2 billion (Kim and Kim 2007). The rationale was that outside, or independent, directors would be in a position to act more independently of internal managers and thus better advocate the position of asset providers. This, of course, is also in-line with some arguments for greater gender diversity on boards of directors.

More recent legislation has touched upon the issue of board of director composition in the financial sector. Korea's Financial Services Commission (FSC) announced that from December 2014, professors and government officials may not serve as outside directors at a major financial institution and the duration of a single appointment would be halved from two years to one (Korea JoongAng Daily 2014; The Korea Times 2014). Regarding the first point, much of the boardroom strife at KB (one of Korea's largest banks) was attributed to the fact that $70 \%$ of outside directors lacked field experience in the financial sector and were deemed unfit to serve as appropriate instruments of checks-and-balances (Korea JoongAng Daily 2014). Regarding the decision to reduce directorship tenure, this was meant to address concerns that an extended directorship would lead to "cozy relations" with management (The Korea Times 2014). The FSC's decision also prohibited concurrent appointments in the financial sector for outside directors.

From these two periods, we can deduce that one clear priority from a legislative perspective has been to enhance the independence of corporate boards of directors. In this sense, there have been clear efforts to ensure an optimal mix of industry experience and independent monitoring ability. At the same time, we have yet to see any official movement on promoting board of director diversity with regards to gender - the argument in the academic literature being that greater gender diversity would result in a diversity of ideas, experiences and enhanced decision-making ability. It is to this point that we examine board of director composition in Korea from the perspective of gender diversity.

To get a better idea about the state of female representation on Korean corporate boards, Table 4 presents relevant data on the top 50 Korean companies listed on the KOSPI as of December 2, 2016. Using data on board composition found in annual filings for each of these companies, we provide a company-level breakdown that should help flesh out the reality behind the numbers. Of the top 50 companies, only 10 (or 20\%) had women directors on the board at the end 2015. Of these 10 companies, only three had more than one female director. Taken as a whole, there were 14 female directors out of 405 in this sample, or roughly $3.5 \%$. 
TABLE 5. NUMBER OF FEMALE DIRECTORS ON KOREAN CORPORATE BOARDS (2015)

\begin{tabular}{|c|c|c|c|c|c|c|c|}
\hline \multirow{2}{*}{$\begin{array}{l}\text { Company Name } \\
\text { Samsung Electronics }\end{array}$} & \multicolumn{3}{|c|}{$\begin{array}{c}\text { Total Female Female } \\
(\%)\end{array}$} & \multirow{2}{*}{\begin{tabular}{|l|} 
Company Name \\
S-Oil \\
\end{tabular}} & \multicolumn{3}{|c|}{$\begin{array}{c}\text { Total Female Female } \\
(\%)\end{array}$} \\
\hline & 9 & 1 & 11.1 & & 15 & 0 & 0.0 \\
\hline SK Hynix & 9 & 0 & 0.0 & Amore G & 5 & 0 & 0.0 \\
\hline Hyundai Motor & 9 & 0 & 0.0 & Hana Financial & 9 & 1 & 11.1 \\
\hline KEPCO & 15 & 0 & 0.0 & Korea Zinc & 9 & 0 & 0.0 \\
\hline Naver & 7 & 0 & 0.0 & Woori Bank & 8 & 2 & 25.0 \\
\hline Hyundai Mobis & 9 & 0 & 0.0 & Kangwon Land & 13 & 1 & 7.7 \\
\hline Samsung C\&R & 11 & 1 & 9.1 & KT & 11 & 0 & 0.0 \\
\hline Samsung Life & 7 & 0 & 0.0 & LG Electronics & 7 & 0 & 0.0 \\
\hline POSCO & 12 & 0 & 0.0 & Industrial Bank of Korea & 6 & 2 & 33.3 \\
\hline Shinhan Financial Group & 12 & 0 & 0.0 & Hyundai Steel & 9 & 0 & 0.0 \\
\hline SK Telecom & 6 & 0 & 0.0 & Hankook Tire & 5 & 0 & 0.0 \\
\hline AmorePacific & 8 & 1 & 12.5 & Lotte Shopping & 10 & 3 & 30.0 \\
\hline KB Financial Group & 9 & 1 & 11.1 & Coway & 7 & 0 & 0.0 \\
\hline SK & 6 & 0 & 0.0 & Samsung SDI & 9 & 0 & 0.0 \\
\hline LG Chem & 6 & 0 & 0.0 & Korea Aerospace Industries & 10 & 0 & 0.0 \\
\hline Kia Motors & 9 & 0 & 0.0 & Hanwha Life & 8 & 0 & 0.0 \\
\hline $\mathrm{KT} \& \mathrm{G}$ & 7 & 0 & 0.0 & Hyundai Glovis & 9 & 0 & 0.0 \\
\hline SK Innovation & 8 & 0 & 0.0 & E-Mart & 7 & 0 & 0.0 \\
\hline Samsung Fire \& Marine Insurance & 7 & 0 & 0.0 & NCSoft & 7 & 0 & 0.0 \\
\hline LG Household \& Health Care & 7 & 0 & 0.0 & Hanon Systems & 9 & 0 & 0.0 \\
\hline Lotte Chemical & 7 & 1 & 14.3 & LG U Plus & 7 & 0 & 0.0 \\
\hline Hyundai Heavy Industries & 6 & 0 & 0.0 & Dongbu Insurance & 5 & 0 & 0.0 \\
\hline LG Display & 6 & 0 & 0.0 & GS & 7 & 0 & 0.0 \\
\hline Samsung SDS & 7 & 0 & 0.0 & $\mathrm{CJ}$ & 7 & 0 & 0.0 \\
\hline LG & 7 & 0 & 0.0 & Average & 405 & 14 & 3.5 \\
\hline
\end{tabular}

Source: respective 2015 annual filings of top 50 Korean firms (based on market capitalization on December 2, 2016), excluding Samsung Electronics (preferred shares) and Samsung Biologics

By industry, we found the highest female representation in boards for the financial industry (3 firms) and consumer industry (3). But as this sample demonstrates, there are so few data points available that empirical studies that try to link gender diversity and corporate performance for the Korean market are nearly impossible. Thus, rather than engaging in an empirical study that examines the link between gender diversity and corporate performance, we aim to discuss some reasons extrapolated from the literature as to why we may be seeing such low female participation in corporate boards, particularly as Korean corporate governance concerns remain a key risk for the market. 


\section{DISCUSSION}

On the one hand, we do not suggest that boards should pursue greater female representation based on the assumption that women are inherently more ethical or innately better at protecting interests of minority shareholders and stakeholders. Indeed, we do not make any claims of moral superiority for either side. On the other hand, the academic literature reviewed in this paper suggest that greater gender diversity on boards can send a positive signal that the board is open to a wide range of experiences and perspectives, which may ultimately aid in monitoring management better (e.g., Hillman and Dalziel 2003). Having board members who bring different insights to the table may generate more constructive discussion and present tougher questions about whether management is acting in the best interest of the firm. Indeed, a corporation that does not appear open to diversity of background on its board may be signaling that it prefers harmony among like-minded individuals rather than engaging in serious discussion about managerial efficiency. This need for diversity may be even more pronounced in a market as ethnically homogenous as Korea.

But despite the potential benefits of female participation in boards of directors, we continue to see low representation of women in Korean corporate boards. In this paper, we look at a few reasons why this may be the case and generate testable hypotheses from these observations.

\section{Low Understanding of Women's Contribution in Enhancing Board of Directors}

With regards to low female participation on corporate boards in Korea, one explanation may be that executives and search committees may be unaware of the potential benefits of greater diversity. For example, Kakabadse et al. (2015) point out that despite numerous studies on gender issues and corporate performance (e.g., Dobbin and Jung 2011), we still do not have a clear understanding of the real effects of women directors on corporate governance. We have also seen in our review of academic literature that the relationship between greater female representation and corporate performance is - to be fair rather mixed. In this sense, it may be too soon to assume that there is adequate understanding about the relationship between gender diversity and its potentially positive effects on board of directors.

We have also highlighted that a firm's posture towards diversity of opinion and perspective would send a positive signal in terms of its commitment to fostering a vibrant and effective board. For example, diversity can provide corporate boards with members who bring diverse experiences, skills and abilities, which is likely to have a positive effect on the effectiveness of management control and supervision (e.g., Bear et al. 2010; Hillman and Dalziel 
2003). In addition, academic literature highlights that women tend to take the director's role very seriously, which may lead to improved corporate governance through more questioning and open discussion (Fondas and Sassalos 2000). Thus, given continued concerns about whether boards of Korean firms are really looking out for the interests of asset providers, serious consideration should be given to the potential benefits of utilizing women directors.

Thus with regards to awareness of women directors' potential contribution to enhancing the function of boards of directors, we generate the following:

Hypothesis 1: In firms where there is lower understanding about women's positive contribution in enhancing boards of directors, there will be a lower number of women directors.

\section{Intentional Exclusion of Female Participation to Maintain Status Quo}

On the other extreme, it may be that Korean corporations are reluctant to have more women directors in an effort to maintain the status quo. In other words, we may be seeing a systematic type of exclusion where harmony and a "rubber-stamping" spirit are key criteria for board membership. In a culture where social networks and golf course negotiations are still common, exclusion of female board members who challenge norms may be a natural, knee-jerk reaction.

Academic research has been quick to acknowledge organizational barriers such as management and "fit," corporate culture, power dynamics, old boys' networks and social exclusion (Ragins and Sundstrom 1989). Oakley (2000) also noted that a critical mass of women in top positions would be a threat to the old boy network, which essentially preserves and enhances rewards for males at the top. This is echoed by those who observe that boards are more likely to develop a questioning culture when women directors are present, thus reducing the likelihood of rubber-stamping management decisions (Kang et al. 2010; Selby 2000).

Given some shared characteristics of national business systems between Korea and Japan, this may help to explain why both countries have such low levels of women on corporate boards and suggest further study may be needed. In Korea's case, we already noted similar issues present in financial institutions whereby concerns on "coziness" between directors and management resulted in legislation reducing directorship tenure and excluded professors and government officials from positions altogether. Thus, we may expect firms that desire harmony over debate to intentionally stifle diversity - including female participation - in corporate boards. From this, we generate the following: 
Hypothesis 2: In firms where executives are more inclined to pursue harmony in the boardroom, there will be a lower number of women directors.

\section{Too Few Female Candidates to Fill Director Posts}

One last explanation for the relatively low level of female participation on Korean boards may be that even if firms wish to bring women directors on board, the candidate pool is too small. For board directors in Korea, objective criteria used to determine suitability include professional background and industry expertise. With the exception of academics, accountants and lawyers, board members tend to be executives (or former executives) of other firms. As such, one reason we see few females on corporate boards may be that there are very few female corporate executives. For example, Singh et al. (2008) examined multiple human capital dimensions of new directors of FTSEiii 100 firms and found that while women are more likely to have MBA degrees, international experience and more experience as smaller firm board directors compared to their male counterparts, new female directors were less likely to have had $\mathrm{CEO} / \mathrm{COO}$ experience.

If this is, in fact, the case, then we must ask ourselves what the root cause of this phenomenon is. While a more in-depth analysis of gender ratios in all segments of the corporate ladder may be needed to provide insight into this question, it may be safe to suggest that issues such as marriage and the gendered nature of childrearing may be prominent reasons for less active female participation in the workforce vis-à-vis male counterparts. For example, Korea is often characterized by patriarchal Confucianism that attributes superiority, authority and power of men over women in family and social relations (Whitley 1991). And while marriage is strongly expected of Korean women, single professional women are often frowned upon and womanhood is often defined by the domestic sphere (Low et al. 2015). It may be possible that this mentality permeates nomination decisions in the boardroom.

In addition, studies have noted that companies in general are slow to remove obstacles to women's careers (Oakley 2000), particularly with regards to childcare responsibilities (Meyerson and Fletcher 2000). In this sense, low female participation in boards of directors may be the result of too few adequate candidates to fill director posts. By extension, low participation of females in middle and upper management positions may further fuel the view that directorships remain with the male sphere of influence. From this, we generate the following: 
Hypothesis 3: In firms where there are a lower number of females in middle and upper management positions, there will be a lower number of women directors.

With regards to awareness-building and nurturing a strong pool of women candidates for corporate boards, groups such as WomenCorporateDirectors (WCD) may be helpful in these respects. As a non-profit organization, WCD focuses on member education and connection and advocates for women on boards around the world. With 78 chapters around the world, WCD launched its Korea chapter in 2016 to raise awareness about the state of gender diversity in Korean corporate boards and to connect female directors with global counterparts. Future research on the efficacy of advocacy through WCD and other channels in light of these hypotheses may also help to enrich the academic debate on board of director diversity in Korea, and help to reveal structural limitations and solutions to encouraging greater board diversity.

\section{CONCLUDING REMARKS}

The academic literature has made a clear theoretical justification for the use of boards of directors to monitor corporate behavior. This is especially the case as there is potential for conflicts of interest between asset providers (investors) and asset deployers (management). If we have an oversight mechanism that can effectively monitor whether asset deployers act in the best interest of asset providers, the argument is that we should expect heightened corporate performance as a result. This performance can be measured both in terms of corporate financial performance and corporate social performance.

The issue of whether corporate boards can benefit from greater diversity in general (and gender diversity in particular) has also been explored in this paper. If anything, having greater female representation on boards sends a positive signal that the board is open to a wider variety of experiences, perspectives and ideas - all of which can be harnessed to check whether management is acting in the best interest of shareholders and stakeholders.

For this study, we introduced data on women representation in corporate boards among OECD nations as well as a more in-depth examination of women directors on Korean corporate boards at the end of 2015. The data suggested that for Korea in particular, female participation in corporate boards continues to be one of the lowest among OECD nations. In this study, we generated testable hypotheses that explore reasons behind low gender diversity in corporate boards. These hypotheses suggest that a lack of awareness regarding benefits of gender diversity, reluctance to open board membership to women and a limited pool of board candidates (due to culture and social networks) may be potential reasons 
that underpin this underrepresentation. Should we wish to encourage greater female participation in corporate boards, we suggest that future research conduct in-depth analyses on fundamental limitations unique to the Korean market and viable solutions to overcome these challenges.

\section{REFERENCES}

Adams, Renee B., \& Ferreira, Daniel. 2009. "Women in the Boardroom and their Impact on Governance and Performance." Journal of Financial Economics 94(2): 291-309.

Baysinger, Barry D., \& Butler, Henry N. 1985. "Corporate Governance and the Board of Directors: Performance Effects of Changes in Board Composition." Journal of Law, Economics, \& Organization 1(1): 101-124.

Bebchuk, Lucian A., \& Weisbach, Michael S. 2010. "The State of Corporate Governance Research.” Review of Financial Studies 23(3): 939-961.

Bloomberg. 2017. "Company Overview of Uber Technologies, Inc." Retrieved at https://www.bloomberg.com/research/stocks/private/board.asp?privcapId= 144524848.

Boeker, Warren. 1997. "Executive Migration and Strategic Change: The Effect of Top Manager Movement on Product-Market Entry." Administrative Science Quarterly 42(2): 213-236.

Bøhren, Øyvind, \& Strøm, R. Øystein. 2010. "Governance and Politics: Regulating Independence and Diversity in the Board Room." Journal of Business Finance \& Accounting 37(9-10): 1281-1308.

Bonn, Ingrid, Yoshikawa, Toru, \& Phan, Phillip H. 2004. "Effects of Board Structure on Firm Performance: A Comparison between Japan and Australia." Asian Business \& Management 3(1): 105-125.

Bonn, Ingrid. 2004. "Board Structure and Firm Performance: Evidence from Australia." Journal of Management \& Organization 10(1): 14-24.

Byrd, John W., \& Hickman, Kent A. 1992. "Do Outside Directors Monitor Managers?:

Evidence from Tender Offer Bids." Journal of Financial Economics 32(2): 195-221.

Campbell, Kevin, \& Mínguez-Vera, Antonio. 2008. "Gender Diversity in the Boardroom and Firm Financial Performance." Journal of Business Ethics 83(3): 435-451.

Carter, David A., Simkins, Betty J., \& Simpson, W. Gary. 2003. "Corporate Governance, Board Diversity, and Firm Value." Financial Review 38(1): 33-53.

CNBC. 2017. "Uber board member David Bonderman resigns after sexist comment at meeting" Retrieved at https://www.cnbc.com/2017/06/13/uber -board-member-david-bonderman-resigns-after-sexist-comment-at-meeting.html 
CNN. 2017. "Ousted Uber CEO Travis Kalanick Shakes Up Board of Directors." Retrieved at http://money.cnn.com/2017/09/30/technology/business/uber-boardtravis-kalanick/index.html

CNN. 2017. "Uber hit by major legal setback in Europe" Retrieved at http://money. cnn.com/2017/05/11/technology/uber-not-tech-company-europe-court/index. html

Daily, Catherine M., Dalton, Dan R., \& Cannella, Albert A. 2003. "Corporate Governance: Decades of Dialogue and Data." Academy of Management Review 28(3): 371-382.

Dobbin, Frank, \& Jung, Jiwook. 2012. "Corporate Board Gender Diversity and Stock Performance: The Competence Gap or Institutional Investor Bias?" North Carolina Law Review 89(3): 809-838.

Earle, Victor M. 1979. "Corporate Governance and the Outside Director - A Modest Proposal." Washington and Lee Law Review 36(3): 787-808.

Erhardt, Niclas L., Werbel, James D., \& Shrader, Charles B. 2003. "Board of Director Diversity and Firm Financial Performance." Corporate Governance: An International Review 11(2): 102-111.

Fama, Eugene F., \& Jensen, Michael C. 1983. "Separation of Ownership and Control." The Journal of Law and Economics 26(2): 301-325.

Farrell, Kathleen A., \& Hersch, Philip L. 2005. "Additions to Corporate Boards: The Effect of Gender." Journal of Corporate Finance 11(1): 85-106.

Goodstein, Jerry, \& Boeker, Warren. 1991. "Turbulence at the Top: A New Perspective on Governance Structure Changes and Strategic Change." Academy of Management Journal 34(2): 306-330.

Haslam, S. Alexander, Ryan, Michelle K., Kulich, Clara, Trojanowski, Grzegorz, \& Atkins, Cate. 2010. "Investing with Prejudice: The Relationship between Women's Presence on Company Boards and Objective and Subjective Measures of Company Performance." British Journal of Management 21(2): 484-497.

Hillman, Amy J., \& Dalziel, Thomas. 2003. "Boards of Directors and Firm Performance: Integrating Agency and Resource Dependence Perspectives." Academy of Management Review 28(3): 383-396.

Hillman, Amy J., Keim, Gerald D., \& Luce, Rebecca A. 2001. "Board Composition and Stakeholder Performance: Do Stakeholder Directors Make a Difference?" Business \& Society 40(3): 295-314.

Jensen, Michael C. 1993. "The Modern Industrial Revolution, Exit, and the Failure of Internal Control Systems." The Journal of Finance 48(3): 831-880.

Joecks, Jasmin, Pull, Kerstin, \& Vetter, Karin. 2013. "Gender Diversity in the Boardroom and Firm Performance: What Exactly Constitutes a 'Critical Mass?"' Journal of Business Ethics 118(1): 61-72. 
John, Kose, \& Senbet, Lemma W. 1998. "Corporate Governance and Board Effectiveness." Journal of Banking \& Finance 22(4): 371-403.

Johnson, Jonathan L., Daily, Catherine M., \& Ellstrand, Alan E. 1996. "Boards of Directors: A Review and Research Agenda." Journal of Management 22(3): 409-438.

Kakabadse, Nada K., Figueira, Catarina, Nicolopoulou, Katerina, Yang, Jessica H., Kakabadse, Andrew P., \& Özbilgin, Mustafa F. 2015. "Gender Diversity and Board Performance: Women's Experiences and Perspectives." Human Resource Management 54(2): 265-281.

Kang, Eugene, Ding, David K., \& Charoenwong, Charlie. 2010. "Investor Reaction to Women Directors." Journal of Business Ethics 63(8): 888-894.

Kilduff, Martin, Angelmar, Reinhard, \& Mehra, Ajay. 2000. "Top ManagementTeam Diversity and Firm Performance: Examining the Role of Cognitions." Organization Science 11(1): 21-34.

Kim, E. Han and Woochan Kim. 2007. "Corporate Governance in Korea: A Decade After the Financial Crisis." U of Texas Law, Law and Econ Research Paper: 123.

Korea JoongAng Daily. 2014. "After KB Debacle, FSC Targets Outside Directors." Retrieved at http://mengnews.joins.com/view.aspx?aId=2997594

Lawrence, Jeffrey, \& Stapledon, Geof. 1999. Do Independent Directors Add Value? Melbourne: Centre for Corporate Law and Securities Regulation: University of Melbourne.

Low, Daniel C.M., Roberts, Helen, \& Whiting, Rosalind H. 2015. "Board Gender Diversity and Performance: Empirical Evidence from Hong Kong, South Korea, Malaysia and Singapore." Pacific-Basin Finance Journal 35(A): 381-401.

Lynall, Matthew D., Golden, Brian R., \& Hillman, Amy J. 2003. "Board Composition from Adolescence to Maturity: A Multitheoretic View." Academy of Management Review 28(3): 416-431.

Maznevski, Martha L. 1994. "Understanding our Differences: Performance in Decision-Making Groups with Diverse Members." Human Relations 47(5): 531-552.

Meyerson, Debra, \& Fletcher, Joyce K. 2000. "A Modest Manifesto for Shattering the Glass Ceiling." Harvard Business Review 78(1): 126-136.

Miller, Judith L. 2002. "The Board as a Monitor of Organizational Activity: The Applicability of Agency Theory to Nonprofit Boards." Nonprofit Management and Leadership 12(4): 429-450.

Muth, Melinda, \& Donaldson, Lex. 1998. "Stewardship Theory and Board Structure: A Contingency Approach." Corporate Governance: An International Review 6(1): 5-28.

Oakley, Judith G. 2000. “Gender-Based Barriers to Senior Management Positions: 
Understanding the Scarcity of Female CEOs." Journal of Business Ethics, 27(4): 321-334.

Peasnell, Ken V., Pope, Peter F., \& Young, Steven. 2005. "Board Monitoring and Earnings Management: Do Outside Directors Influence Abnormal Accruals?" Journal of Business Finance \& Accounting 32(78): 1311-1346.

Pelled, Lisa H. 1996. "Demographic Diversity, Conflict, and Work Group Outcomes: An Intervening Process Theory." Organization Science 7(6): 615-631.

Pfeffer, Jeffrey \& Salancik, Gerald R. 1978. The External Control of Organizations: A Resource Dependence Perspective. New York: Harper \& Row.

Pfeffer, Jeffrey. 1972. "Size and Composition of Corporate Boards of Directors: The Organization and its Environment." Administrative Science Quarterly 17(2): 218-228.

Post, Corinne, \& Byron, Kris. 2015. "Women on Boards and Firm Financial Performance: A Meta-Analysis." Academy of Management Journal 58(5): 1546-1571.

Ragins, B. R., \& Sundstrom, E. 1989. "Gender and Power in Organizations: A Longitudinal Perspective.” Psychological Bulletin 105(1): 51-88.

Raheja, Charu G. 2005. "Determinants of Board Size and Composition: A Theory of Corporate Boards." Journal of Financial and Quantitative Analysis 40(2): 283-306.

Selby, Cecily C. 2000. "From Male Locker Room to Co-ed Board Room: A Twenty-Five Year Perspective." In Burke R.J. and M.C. Mattis (eds) Women on Corporate Boards of Directors. Issues in Business Ethics (14).

Singh, Val, Terjesen, Siri, \& Vinnicombe, Susan. 2008. "Newly Appointed Directors in the Boardroom: How do Women and Men Differ?" European Management Journal 26(1): 48-58.

The Economist. 2012. "The Korea Discount: Corporate Governance Explains South Korea's Low Stockmarket Ratings." Retrieved at http://www.economist.com/ node/21547255

The Korea Times. 2014. "Outside Directors Face Tougher Regulations.” Retrieved at http://www.koreatimes.co.kr/www/biz/2017/10/488_168502.html

The New York Time. 2017. "Uber Discriminates Against Riders With Disabilities, Suit Says" Retrieved at https://www.nytimes.com/2017/07/18/nyregion/uberdisabilities-lawsuit-new-york-city.html

The New York Times. 2014. "Uber Banned in India's Capital After Rape Accusation" Retrieved at https://www.nytimes.com/2014/12/09/world/asia/new-delhi-bans -uber-after-driver-is-accused-of-rape.html

The New York Times. 2014. "Uber Is Ordered by Spain and Thailand to Halt Operations" Retrieved at https://www.nytimes.com/2014/12/10/technology/uber-isordered-by-spain-and-thailand-to-halt-operations.html 
The New York Times. 2015. "South Korea Vows 'Strong Crackdown' on Uber" Retrieved at https://www.nytimes.com/2015/02/06/business/international/ south-korea-uber-crackdown-vowed.html

The New York Times. 2016. "Uber and Its Executives Are Fined in France" Retrieved at https://www.nytimes.com/2016/06/10/technology/uber-and-itsexecutives-fined-in-france.html

The New York Times. 2016. "Uber Driver Napped as His Passenger Led Highway Chase, Police Say" Retrieved at https://www.nytimes.com/2016/04/07/nyregion/ uber-driver-napped-as-passenger-led-highway-chase-police-say.html

The New York Times. 2017. "Morning Agenda: Uber Investor Sues Ex-C.E.O. Travis Kalanick" Retrieved at https://www.nytimes.com/2017/08/11/business/ dealbook/uber-lawsuit-travis-kalanick.html

The New York Times. 2017. "Uber Chooses Expedia's Chief as C.E.O., Ending Contentious Search" Retrieved at https://www.nytimes.com/2017/08/27/ technology/uber-ceo-search.html

The New York Times. 2017. "Uber Fires Executive Over Handling of Rape Investigation in India" Retrieved at https://www.nytimes.com/2017/06/07/ technology/uber-fires-executive.html?mcubz $=0$

The New York Times. 2017. "Uber Founder Travis Kalanick Resigns as C.E.O." Retrieved at https://www.nytimes.com/2017/06/21/technology/uber-ceo-traviskalanick.html

The New York Times. 2017. "Uber Investigating Sexual Harassment Claims by Ex-Employee" Retrieved at https://www.nytimes.com/2017/02/19/business/ uber-sexual-harassment-investigation.html

The New York Times. 2017. "Uber Is Sued by Woman Who Was Raped by One of Its Drivers in India" Retrieved at https://www.nytimes.com/2017/06/15/ technology/uber-india-rape-lawsuit.html

Watson, Warren E., Johnson, Lynn, \& Merritt, Deanna. 1998. "Team Orientation, Self-Orientation, and Diversity in Task Groups: Their Connection to Team Performance Over Time.” Group \& Organization Management 23(2): 161-188.

Whitley, Richard D. 1991. "The Social Construction of Business Systems in East Asia." Organization Studies 12(1): 1-28.

Williamson, Oliver E. 1983. "Organization Form, Residual Claimants, and Corporate Control." The Journal of Law and Economics 26(2): 351-366.

World Bank. 2016. "Women, Business and the Law 2016: Getting to Equal." Retrieved at http://wbl.worldbank.org/ /media/WBG/WBL/Documents/Reports/ 2016/Women-Business-and-the-Law-2016.pdf 